\title{
Female Sexuality in Contemporary Pakistani English Fiction
}

\author{
Asim Karim \\ University of Central Punjab, Lahore, Pakistan \\ asim.karim@ucp.edu.pk
}

\begin{abstract}
Female sexuality has remained a taboo subject in Pakistani literary and cultural representations. However, a considerable shift has occurred in contemporary Pakistani English fiction. Focusing on female bodily behaviour, the fiction explicates multiple shades of female sexual relations and experiences outside the cultural and religious norms in an unusually direct and explicit fashion. This study analyses the way Pakistani fiction, written in English, responds to the variety of different ideologies imposed upon women's bodies and sexuality. It analyses some key sexual experiences of pubertal sexual awakening, postmarital sex, women's urge for proactive sexual intercourse, and disavowal of motherhood, pregnancy and birthing. The collective representation of female sexuality in each case embodies a transgressive experience outside the shame/shameless, licit/illicit binaries. However, the representation, despite its explicitness, does not constitute in any way women's sexual autonomy against the predominant masculine discourses. The issues have been analyzed within the framework of debates on the female body, heterosexuality, the male gaze and commodity fetishism.
\end{abstract}

Keywords: Pakistani English fiction, female sexuality, compulsory heterosexuality, the Male Gaze, Commodity fetishism

'[S]exual autonomy and bodily rights lie at the core of women's human rights, and notions of equality and empowerment cannot be applied to daily life unless sexual and bodily rights are fully realized' (Amado quoted in Shannahan, 2009: p. 61)

\section{Introduction}

The female body, especially in terms of a sexualized being, has been the epicenter of a wide range of thematic and theoretical interpretations on 'the ways female bodies are talked about, classified, disciplined, invaded, destroyed, altered, decorated, pleasured. . ' (Brook, 2014: p. 2). Undergoing phenomenal theoretical 
exposition since over the period, focus on the female body has moved from materiality of the body to postmodern questioning of 'the givenness and security of the so-called natural body, positing instead a text corporeality that is fluid in its investments and meaning' (Price and Shildrick, 1999: p. 1). The feminist debates on the subject, however, do not represent a uniform methodology. The constructivists within the feminist area, for instance, are deeply preoccupied with 'the way women's and men's bodies are differently and unequally imbued with social meanings' (Brook, 2014: p. 11), seeing the body 'as a kind of natural biologically sexed object that pre-exists but is affected by the workings of culture or, as some writers term it, a tabula rasa: a blank surface ready to be inscribed' (ibid., p. 11). Butler and Irigaray, on the other hand, deconstruct the essentialist or constructivist positions to demarcate the female body with performativity and fluidity, respectively. While Butler explains gender as a continuing performance, Irigaray places "stress on multiple forms of female embodiments, the self-touching, 'two lips' that characterize female morphology and fluidity that marks the inherent excess of the feminine that is uncontainable within binary sexual differences" (Price \& Shildrick, 1999: p. 6). In postcolonial theory, female body as Ashcroft, Griffiths and Tiffin say appears to be a "literal text on which colonisation has written some of its most graphic and scrutable messages and 'literal site" on which resistance and oppression have struggled ...' (p. 322). It appears to be a powerful source of enacting "the 'difference' of the post-colonial subject by which s/he can be 'othered", transforming the superficial differences of the body and voice "as indelible signs of the "natural' inferiority of their possessors" (Ashcroft, Griffiths \& Tiffin, 1995: p. 321). Fannon also eloquently describes the women and oppression in postcolonial Algerian experience: 'Algerian women are placed in a metonymic process where both veil and woman become interchangeable, scopic signifiers of colonized Algeria itself - as oppressed, inscrutable, and dispossessed' (as quoted in Kanneh, 1995: p. 346). Katrak's in her study Politics of the Female body: Postcolonial Women Writers of the Third World argues that 'the female body is in a state of exile including self-exile and self-censorship, outsiderness, and unbelonging to itself within indigenous patriarchy . . . strengthened by British racialized colonial practices in the regions of India, Africa, and the Caribbean that this study covers' (2006: p. 2). The debates, though meaningful, have not been contextualized to analyze issues of female sexuality in contemporary Pakistani fiction.

Pakistani society broadly represents a threshold condition of an uneasy state of intense conflict between religiosity and the secular modernization. Attitudes to sexuality in this context have varied from prohibition, complete abstinence outside marriage to liberal premarital or extramarital sexual conduct. Collectively, the social depictions of male and female sexuality are replete with paradoxes and 
double standardization (Hubbard, 1976) of different attitudes for male and female sexualities. While male sexuality tends to be ignored from being severely monitored or reprimanded, female sexuality in the culture is thoroughly monitored, and regulated with severe repercussion in case of detection of the violation of prescribed. Likewise, while male illicit sexual trespassing is not included in the honor/dishonor, shame/shamefulness discourses and women's sexuality is subjected to all these processes. Virginity discourse also specifically concentrates on women to highlight the significance of the intact form of the hymen for the stability, success and happiness of their marital lives. Ruptured hymen conversely leads to adverse reactions from stigmatization to murder and permanent disability to get married honorably. Mernissi in her Virginity and Patriarchy (1982) contends that the preservation of hymen is very crucial for the girl and in order to present their hymen intact, they resort to even surgery before marriage to get rid of traces of premarital sexuality. Ali highlights the same. In one of her introductory remarks, Ali states, 'the essence of women is reduced to hymen' (2006: p. xi), generating debates like 'a girl with ruptured hymen is like a used object' (Ibid., p. 12), unworthy of respectable existence. This mindset generates a whole range of acts that principally aim at not only repudiation of the female victim, but also many unthoughtful procedures like 'name calling, expulsion or confinement, and may lead to shotgun wedding to a man either who is responsible for the defloration or to some generous man willing to cover family shame ...' (Ibid., p. 12).

In this context, Pakistani fiction holds a peculiar significance for exposing female body and sexuality to multiple connotations which have generally remained an oppressed subject in Pakistani literature written in Urdu and other regional languages. Munto is certainly an exception as he has written explicitly about the tabooed subject of female sexuality in his short stories. On the whole, however, Pakistani writers have tended to treat the sexuality of women as an excluded other, and an incongruous subject for bold literary treatment. Contemporary English fiction represents the female body and its sexual orientations in a way that cannot be paralleled with any conventional representation in our national literature. Pleasures of body, female desire, an urge for illicit/licit heterosexual genital contact and incitement to oral sex (Ice-Candy man) are now represented in the fiction. It undoubtedly is a transgressive intervention into the standardized creative pattern in the national culture. Writers like Uzma Aslam Khan, Bapsi Sidhwa, Danyal Mueenuddin, and Nadeem Aslam keenly expose the female body to the enactment of cultural power and various shades of female sexuality. The male body, except in Hanif Kureshi's short story titled "Penis", where we have an extravagant linguistic playfulness with the male sex organ, and a reference to Lenny knowledge of her cousin's genital in Ice-Candy man (...His genitals have grown since I last examined them ... (Sidhwa, 2012, p. 161)), the corporality of the male body is not 
emphasized in the text. It is the female body which continues to appear scintillatingly in the various texts. Naqvi in his narrative digresses to debates on sociocultural factors that inform 'ah groans women emit during the intercourse' (Naqvi, 2010: p. 89). The grunt is 'primal and instinctive, but anecdotal evidence suggests that women from different nations don't groan the same way. .' (Ibid., p. 89).

However, there is a need for being cautious about the implications of this bold treatment. Seemingly, women in contemporary Pakistani English fiction experience sexuality independent of cultural, religious and other preexisting regulations concerning premarital, extramarital or pubertal sexual behaviour. Also, fear of the stigma of promiscuous behavior, especially in premarital or extramarital sex does not seem to impact their choice of sexuality as evident in Saleema and Lilly in Mueenudin's short stories. Women also seem to invoke different subjectivities and prefer not to comply with the prevalent gendered sexual and prefer to inhabit different sexual behaviour as evident in Lilly's adulterous relations with Bunty. Hence, they appear to contradict relationship between misogyny and 'the creation of passive feminine bodies' (MacLaren, 1997: p. 115), between a "docile" and "manipulable body" and "the regimes of disciplining and regulatory practices that shape its form and behavior' (Price \& Shildrick, 1999: p. 8). They seem to imbibe a spirit of empowerment and independence, exposing their bodily "surfaces and orifices" (Butler, 1990: p. 169) to multiple "erotic signification" (Ibid., p. 169). However, the tendency, though bold and unconventional in a unique fashion, should not be confused with the feminist debates on "agency" (Davies, 1991; McNay, 2013) and women emancipation from the gendered stereotypes. Contrarily, in all sexual representation of women, there are palpable signs of misogyny and masculinity (Seilder, 2013), representing the way men author it. Thus, female sexual expressions here might appear to "reinscribe" (Butler, 1990: p. 169) a new domain for women to express autonomy from exclusion and oppression, and/or 'contest the place and authority of the masculine positions' (Ibid., p. xxvii-xxviii ). But, on the whole, it cannot be presumed as a "dialectical reversal of power" (Ibid., p. xxviii). Women bodily "surfaces and orifices" (Ibid, p.169) are shrouded in the stereotypes of gendered configurations, and they continue to construct the fixed binary relation between man and women with related troubling masculine discourses. Therefore, Pakistani fiction reincarnates what Butler calls "single drama that acts on the body" (Ibid., p. 167), representing "an inscription from a cultural source figured as 'external' to the body" (Ibid., p. 167). This is the underlying paradox and will be analyzed concerning Rich's notion of "compulsory heterosexuality" Mulvey's concept of "The Male gaze", and Marxist proposition of "commodity fetishism". 
The present study, comprising two parts analyses the concerns mentioned above with reference to theoretical repertoire on body, desire and women role in heterosexual relations. The first part attempts to debate how women in Pakistani English fiction can express their sexual being irrespective of the cultural inhibitions. The second part, on the other hand, explains how these sexual expressions are paradoxical enunciation of misogyny and masculine power discourses.

\section{Female Adolescent Pubertal Sexual Awakening: Possibilities and Empowerment}

Puberty is integral to the sexual development of an adolescent and expressions of knowledge of pubertal changes may embody the ways boys/girls can develop attitudes towards 'four hallmarks of adult sexuality: sexual desire; sexual arousal; sexual behaviors; and, sexual function' (Fortenberry, 2013: p. 280). Puberty is also replete with:

'Fundamental challenges for young people. These include adjusting to the altered appearance and functioning of a sexually maturing body, learning to deal with sexual desires, confronting sexual attitudes and values, experimenting with sexual behaviors, and integrating these feelings, attitudes, and experiences into a developing sense of self' (Crockett, Raffaelli \& Moilanen, 2003: p.371).

Depending upon cultural prescriptions and inhibitions, puberty might later enable them to exercise their choice and freedom in man-woman heterosexual relation. From female perspectives, puberty is closely tied to the way cultures inform female sexual behaviour. As Chodorow argues it is 'an important ingredient in any woman's or man's love or sexual fantasies, erotic desires, and behavior will be found in her or his particular unconscious and conscious appropriation of a richly varied and often contradictory cultural repertoire...' (2014: p. 79). Mostly, Chodorow argues 'Women seek directly to reconstitute, resurrect, reshape, reimagine an emotional relation with their mothers; they fantasize and unconsciously experience internal and actual mothers even as they form relationships with men' (Ibid., p. 82). Butler also argues that "the sex/gender distinction and the category of sex itself appear to presuppose a generalization of 'the body' that preexists the acquisition of its sexed significance" (1990: p. 169). Thus, culture licenses or constrains the knowledge about your sexed being. 
Similarly, culture informs how women can create their subjectivities about the freedom of sexual experiences. Subject to the cultural spontaneities, women sexual expressions might also be tied to the sexual knowledge about their erotogenic zones as well as the amount of sexual pleasure/anxiety they elicit during their pubertal growth.

Furthermore, the culture can inform sexual inhibitions for the female subjects through its discourses about what is permissible and not permissible to women in sexual spheres. In a conservative cultures like Pakistan, the discourse of shame, (Idris \& Abbas, 2010) tends to be applied on women more rigorously than on men and it is generally considered shameful if women speak about the knowledge of their erotogenic zones, their pubertal developments and/or amount of pleasure/anxiety they undergo during the pubertal process. On the contrary, it is considered to be natural and normal if women, especially the adolescents, remain silent about sexual awakening and sexual pleasure associated with pubertal development in the body.

Contemporary Pakistani writers like Sidhwa exposes these areas in an uncharacteristically direct fashion, challenging social conformity to certain preordained gender practices Sidhwa is first amongst the contemporary Pakistani writers to destabilize shackles around the issues of female sexual expressions, candidly describing female adolescent sexual awakening along with the associated body pleasures and anxieties in her novels Ice-Candy man and The Pakistani Bride. Born in a prominent Parsee family in Karachi, Sidhwa has grown into an internationally acclaimed Pakistani diaspora novelist. Many of her novels relate to 'history and changing social and political structures of her community and her country across the entire twenty century through three novels the crow eaters, IceCandy-Man and An American Brat' (Shamsie, 2017: p. 195). The Pakistani Bride, Earth and Water are her other significant novels. Ice-Candy man, in particular, is an embodiment of female oppression in the backdrop of Indo-Pakistan partition in 1947. From the feminist perspective, the novel as Choudhury (2018) articulates, 'exposes how female characters, young and old, are positioned within the genderspecific roles through patriarchal biases centered on the female body. Sidhwa allows us to see how female body remains the most important entity for female figure in its ability and disability as it assigns meaning in the gendered world of Sidhwa's Ice-Candy man' (p. 33 ). Politically, the novel narrates, how 'The female body in Ice-Candy man becomes a site on which the different religious communities inscribe their messages of revenge and express their frustrations. To kill or rape a woman of the other religious community becomes a violation of the sacred space of the other' (Ibid., p.56). The Pakistani Bride also contextualizes the post-partition migration of people across the borders of newly independent states of 
Pakistan and India. The storyline centers on a girl, named Zaitoon is who is rescued by a tribal man Qasim from trains attack as Muslim refugees cross the border into Pakistan. Initially, they live in Lahore for a year, but later on, Qasim prefers to take her to his tribe and decides to marry her to his nephew called Sakhi. The marriage is simply a disaster for young Zaitoon and she prefers to escape from her 'hellish' post-marriage life to Lahore.

The analysis is concerned with the way Sidhwa represents adolescent girls' growing knowledge about their pubertal developments and different behavioral expressions associated with it. Leny and Zaitoon reaction to their pubertal changes in Ice-Candy man and The Pakistani Bride respectively reveals how they undergo psychological phases, like curiosity about her genital development and bodily changes at reaching puberty. Lenny's sexual awakening, especially gaining knowledge about her growing breasts, introduces her to a sense of an independent self, quite distinct from the others. Most significantly, and contrary to the cultural inhibitions, the newly gained knowledge of their erotogenic zones is strongly selfempowering and pleasure-inducing, filling her with power to guard it with utmost resilience and confidence on the prospects of having an attractive body in the future. She examines her chest in the wall mirror and "play with them as with cuddly toys. With my limp and my burgeoning breasts - and the projected girth and wiggle of my future bottom - I feel assured that I will be quite attractive (Sidhwa, 2012: p. 213). Possessive about her identity, she feels captivated by her sexual growth: 'Two little bumps have erupted beneath my nipples. Flesh of my flesh, exclusively mine. And I am hard put to protect them. I guard them with a possessive passion ... Only I may touch them ... Not anybody. I can't trust anyone' (Ibid., p. 213). On the same pattern, Zaitoon's knowledge of her body has also been meticulously narrated. In recalling her moment of puberty, she describes feelings of joy on discovering the promised womanhood. Suddenly, shy of discovering the "slight taut swell in her flesh", she glanced at herself in the bathing glass. With crooked neck and probing fingers, she "probed the enchanting novelty ... softness was delicious to the touch to her childish inquisitive fingers ... this way or that ... pummeling and distorting...' (Sidhwa, 1983: p. 232). Onwards, she longs for the privacy of bathing each day, to repeat the ritual experiencing her body.

A substantial difference is also apparent in the ways Ayah, Leny and Carol react to male intrusion into their bodies. While Ayah allows male intrusion in the form of masculine touch and "lightning strikes of Ice-Candy man's toes" (Sidhwa, 2012, p. 72), Carol, likewise is inclined towards a promiscuous relationship, purposefully exposing her body to the male gaze, and later on revels in "appreciativeness of his stare" (Ibid., p.112). Leny, on the other hand, resists such attempts on the part of 
her cousin. She is conscious of her body as her cousin advances to caress her, 'she draws back, slapping his hands till my palms sting.... If you ever do that again, I'll break your fingers knuckles by knuckles ...' (Ibid., p. 224). Later on, she arrives at a compromise to her advantage, 'We arrive at a compromise, a finely delineated covenant. I will keep an open mind and let bygone be bygones, and cousin will stop wooing me and wait a couple of years before touching my beasts again' (Ibid., p. 225).

\section{Communicating Desire: No longer passive, but active women}

Women's ability to express their desire in any heterosexual contact is also fraught with discourses and carries a substantial significance for gender studies (Kiefer \& Sanchez, 2007). Again, culture is at the center of these debates, as Henningsen, Henningsen and Valde (2006) uphold, revealing how women's level of sexual interest (or lack of it) affects the way females are perceived in and also determines acceptance and rejection of heterosocial interaction and sexual concerns. In this context, cultural constraints on women to initiate sex, express desire, communicate it to a male partner, and show openness to sexual communication before or during a heterosexual experience is of critical importance in a conventional society. Like other spheres of female marginalization, cultural taboos on the issues above impose substantial constraints on women to be expressive of desire. Equally important is the issue of her passivity in sex experiences like intercourse. The prevalent cultural norms in a conventional society like Pakistan assume women's silence on matters of expressing desire, initiating sex and remaining passive as a usual and natural way to man-woman sexual interactions. Predominantly, women's ability to communicate interest in sex even in marital relations is confounded with shame/shamelessness discourse and negatively impacting male's perception of her character. Mueenuddin, however, challenges these norms. Born in Southern Punjab, Pakistan, he has acquired international acclaim through his short-story collection In Other Rooms, Other Wonders (2009). The collection consists of stories about the impoverished and powerless classes of domestic servants and their dominant feudal masters with absolute clarity and precision. Apart from the social reality, Mueenuddin challenges gender norms prevalent in Pakistani society and represents women as proactive partners in heterosexual love, demanding sex, desiring the vaginal intercourse loudly and even taking control of the sexual experience. The short story "Lilly" is of critical importance on the subject. Through the characters of Murad and Lilly, an elite class couple, the story reveals an under growing tension between the man and women on different attitudes within marital sex. While Lilly needs a strong expression of sexuality, her husband Murad 
is inclined towards passivity and a kind of disinterest in sex overwhelms him gradually. Mueenuddin consistently questions it, focusing explicitly on women's sexual pleasure in this story. This is how he describes Lily's propensities to dating and sexual excitement:

'They [Lily and Murad] slept together for the first time only a few weeks before the wedding, tenderly, gravely__ clumsily both of them, after having resisted so long. She had brought new sheets, took down the bright embroideries .... Instead decorating with white hand-woven cotton, a new bedspread, new chairs.... And in that setting removed her clothes by candlelight, passing herself to him' (2009: p. 199).

She profoundly desires an impulsive, proactive and vigorous sexual relationship, the absence of which soon after marriage drives her to frustration and an adulterous transgression with Bumpy. She found Murad cold, casual and placid in the bed, 'always did it the same way, on top, and became shy when she suggested, by her movements, that they try other positions' (Ibid., p. 205). The persistence of his shyness naturally placed limits on their physical intimacy had disappointed her urge for open, frank, unreserved sexuality, which is finally realized in unrestrained adulterous relations with Bumby. She took the initiative, guided Bumby to the pool for bathing together, "Bumby clothes fell. . . Lilly pulled her blouse overhead ..." (Ibid., p. 212) and later after the bath, she "guided him inside her" (Ibid., p. 213), "held him inside her, legs around his waist" (Ibid., p. 213) until "desire crushed entirely" (Ibid., p. 213). The entire depiction is replete with an unconventional openness and directness that amalgamate the dichotomous boundaries between lust and desire to create an impression of a woman who can communicate her passion and act in a way which is analogous to an independent woman. It also deviates from the regular creative textual representation of female desires in the national literature and marks an altogether new approach to describe human sexuality and its manifestations in creative art. She is also obsessed with her body being watched unnoticed, 'sitting on her haunches by the fireplace, she took a match and lit the rolled newspaper. She thought of doing this watched by another man a few weeks ago, feeling his eyes on her, admiring her, judging her body, back held straight, her blouse tight around her slender waist...' (Ibid., p. 184).

Uzma Aslam Khan also constructs the same in her The Geometry of God (2008). Born in Lahore, Pakistan, Uzma lives now as a Pakistani- American diaspora, deeply concerned with the cultural heritage of Pakistan. Her major works include Trespassing (2003), Thinner Than Skin (2011) and The Miraculous True History of Nomi Ali (2019). The Geometry of God is about the historical, ideological and cultural dialectics between orthodox Islamic attitudes and the secular worldview 
which dichotomies the relationship between the two in conflicting camps. Female sexuality is not the principal subject of the novel, but the sexual relationship between Mahwish and Nouman is replete with a woman's expressive response to heterosexuality. It is an aggressively direct and an uninhibited enunciation of marital heterosexual vaginal intercourse, where woman moves out of passivity to act proactively in an unusual posture:

'.... the night after that he slides hands under my nightie and cups my breasts leisurely, sliding a thumb around each nipple. His patience eases me. He's back to being a panther with time, not a twitchy bat. He sits up, positions me so my back rests against his chest, lifts the thin satin higher, and doesn't take it off. He slides a light hand over my stomach, over my underwear, does not take it off. Slides a finger into me, thickens behind me. He strips me drooling on my neck. Such pleasure, when there is in pain! I push down. "I'm going to keep you in". He lurches higher into me. "Not yet. I'm going to keep you in". He tries to slow down. In the middle of night, dreaming of Omarish sinuosities, I crawl on top again' (Khan, 2007: p. 325).

\section{Immigration, Islamism and Female Sexuality}

Female sexuality in Pakistani Fiction is deeply engrossed with the broader multicultural and global issues related to Muslim migrant families in the West. A wide range of studies has recently drawn attention to the problems, processes and anxieties of acculturation of Muslim immigrants, especially youths to the liberal Western societies. Understandably, acculturation takes place as a process which as Espin (2013) contends could be both liberating and restrictive, liberating in the sense that it increases their options for self-fulfillment, and restrictive because it enhances patriarchal concerns for more restrictions on them (Espin, 2013). Likewise, Yip (2009) discusses the friction between religious attitudes and liberal sexualities in the West. Religion and sexuality, argues Yip are not compatible with broader social and cultural developments in the secularized West where 'religion is generally perceived as sex-constraining (i.e. it hegemonizes heterosexual maritalsexuality and constructs all other forms of expression as an unacceptable "Other", if not sex-negative (i.e. it represses and oppresses believers as sexual beings, thus undermining their humanity)' (p. 1). In an interesting study on the acculturative processes and adolescent sexuality of immigrant adolescents from Islamic background, Yahyaoui et al. argue that the contemporary west is characterized by growing permissiveness for the young people and children "to a steady stream of 
information and highly explicit sexual imagery" leading to indulgence in sexual activities without any consideration for the shame or sin perspectives. For immigrants from an Islamic background, religion's greater role could be identified in "Dos Don't Indicator" (2013: p. 29).

The same conditions apply to the immigrant Muslim as represented in Shamsie's Home Fire (2017). Shamsie is a prolific Pakistani diaspora writer of international acclaim for her insightful account of multicultural, religious and conventional Pakistani lives in her fictions like Broken Verses, Cartography, Burnt Shadows, A God in Every Stone. Mainly, she represents influential Muslim diaspora voices on plenty of cultural and political issues related to the Muslim in London. The novel explicitly demonstrates how pot 9/11 has developed the 'Othering' of the Muslim communities in the west. It mainly deals with a Pakistani migrant family to England. The family consist $\mathrm{s}$ of Isma (elder sister) and the adolescent twins, Aneeka and Pervaiz. Aneeka here exposes some of the problems as mentioned above in the Muslim girl's propensity to sexuality and the religious indicator of do's and don'ts. Born in a religious family (her father was charged with supporting militant Jihadism), Aneeka is split between bodily desires and religious/cultural prohibitions, her "covered head, and the naked body" (Shamsie, 2017: p. 88) amply signify the female body as a site of the cultural inscriptions as Butler says. From the transgressive sexualities perspectives, Aneeka's inclination to sexual relationships outside marriage is an abortive attempt to exercise her right to individuation and expressions. Eamonn, the son of liberal British Home secretary, Karamat Lone, finds her ways too strange to be comprehended and perturbed to think about duality in Aneeka's mindful division between the pursuit of desires and religious inhibitions. With his father speech "don't set yourself apart the way you dress" (Shamsie, 2017: p. 88), Eamonn's uneasiness is visible while watching a video recording of Aneeka:

'Standing up from her prayer mat and walking into his embrace, shedding her clothes along the way until only the hijab remained. The video would not reveal the things that were most striking about her in those moments: the intensity of her concentration, how completely it could swerve from her God to him in the time needed for those few steps; or her total lack of self-consciousness in everything she did- love and prayer, the covered head and the naked body' (Shamsie, 2017: p. 88).

Understandably, Aneeka's character is an embodiment of cultural polarizations between different cultures and how it is liable to generate a state of conflict between people who follows the different cultural norms. From sexuality perspective, Aneeka's split between covered head and naked body 
once again symbolizes the entrapment of women body in desires for male sexual pleasure.

\section{Disavowal of Birthing and Motherhood}

Feminist debates are poised to challenge women reproductive capacities (pregnancy/birthing) to critique misogyny under different threads of thoughts. It would be pertinent here to refer to the radical feminist Shulamith Firestone's disavowal of birthing. Her extreme account of total abnegation of motherhood is characteristic of the radical feminist critique of female reproductivity. To her "child-bearing is a sort of dirty trick played by nature on women (Brook, 2014: p. 6) and giving birth is compared to "shitting a giant pumpkin" (Ibid., p. 6), heralding "the development of artificial wombs as a mode of salvaging women from nature and 'the temporary deformation of the body of the individual for the sake of the species" (Ibid., p. 6). Recently, the debates on birthing and pregnancy have expanded to draw attention to a wide range of issues surrounding "pregnant embodiment", "fatness" and "bigness" concerning "women self" during pregnancy. The issues predominantly reflect anxiety "surrounding the maintenance of an appropriate feminine 'self' and the appearance of slenderness or normalised beauty in early pregnancy" (Nash, 2012: p.2). Though not a very thematic concern in Pakistani fiction, 'disavowal of birthing' and the relation of pregnancy to 'fatness' interestingly appear in Mueenuddin's short story "Lilly", where the protagonist Lilly expresses in no uncertain words her aversion to the thought of stepping into the post-marital reproductive process of pregnancy and birthing. In response to Murad's (husband) desire that she must "leap into childbearing in this first surge of their marriage" (Mueenuddin, 2009: p. 204), Lily reflects upon 'the pain, her body torn and stretched, the body that she cared so much about, which she had entirely lived for, its pleasures, wine and intoxication, clothing herself, pleased by herself in the mirror, undressing in front of men, silently expectant. And then to be hostage to child, fighting against it ...' (Ibid., p. 204). The aversion to birthing is a meaningful explication of her fixation with her body and the effects of reproductive compulsions on her physical structure. Besides, it powerfully represents the radical feminist position on mothering, pregnancy and birthing. Her reticence on birthing replicates Firestone's famous disavowal of reproduction as 'shitting a giant pumpkin'. 


\section{The Paradoxes of Female Sexuality}

This section is an explication of how female sexualities as discussed above is paradoxical, as women's ability to experience sex in an unconventional fashion does not constitute their sexual freedom or their transformation from silence and exclusion to social empowerment. Contrarily, it reincarnates masculine power discourses, explicated here with reference to three disparate notions of "compulsory heterosexuality," "male gaze," and "Commodity Fetishism."

\section{Compulsory Heterosexuality}

The notion of "compulsory heterosexuality," as developed by Rich (1980), deprecates women's sexual capacities and status. Butler also says, "the disciplinary production of gender effects a false stabilization of gender in the interests of the heterosexual construction and regulation of sexuality within the reproductive domain" (1990: p. 172). Analyzed in the framework of Butlerian "repeated stylization of acts," the heterosexual acts re-affirm the body as a preexisting condition, where sex "is an obligatory injunction for the body to become a cultural sign, to materialize itself in obedience to historically delimited possibility" (Ibid., p. 172) and not as a place where "gender discontinuities that run rampant within heterosexual, bisexual, and gay and lesbian contexts .." do not impinge upon women identities or gender configurations. Rich argues that her essay "Compulsory Heterosexuality and Lesbian Existence" (1980) was 'not written to widen division but to encourage heterosexual feminists to examine heterosexuality as a political institution which disempowers women-and to change it' (p. 1591) Underscoring the negative implications of heterosexual ties, Rich states that it restrains women from realizing their complete sexual and emotive capacities and denies them any other sexual way that is not directly related to male pleasure. The ultimate impact of this heterocentricity of the sexual relationship between man and woman is to allow men to have their will. Rich (1980) explains it regarding Catherine Gough's eight characteristics of male power: 'men's ability to deny women sexuality [as Murad does in Lily] or to force it upon them; to common or exploit their labor to control their produce; to control or rob them of their children; to confine them physically; prevent their movements, or use them as objects in male transactions; to cramp their creativeness, or to withhold from large areas of society's knowledge and cultural attainments' (p. 1594). In this context, stress on heterosexual relations in Pakistani fiction, especially from the women's side, is strongly restrictive and hardly deviating from heterocentricity, the women's desire for sexuality generates the subordinate female positions in sexual relations. It 
restrains women from realizing their complete sexual and emotive capacities and denies them any other sexual way that is not directly related to male pleasure. The ultimate impact of this heterocentricity on sexual relations between men and women is to allow men to have their will.

As Butler and Rich underscore, heterosexual relations signify male domination (in one way or the other). On many occasions in narrating man-women sexual bonds, the fiction demonstrates men's power to control women's desire (as in Lilly) or to force sexuality upon them, where female body is merely a reproductive site for more and more children as in Mueenudin's story of "Nawab din Electrician," where Nawab's unnamed (un-naming is symbol of her marginalized condition) wife fully represents a docile embodied self, lacking reproductive and sexual autonomy, and ensnared in male sexual desires. Reduced to domesticity (physical work like cooking and feeding, revealing economic dependence), she is the reproductive entity for Nawab's limitless sexuality and appreciated and prized for her "unsurpassed fertility" (Mueenuddin, 2009: p.14). Giving birth to twelve girls "spaced, if not less than nine months apart" (Ibid., p. 14) until she was able to give birth to "the looked for son" (Ibid., p. 14). The story "Saleema" replicates the same. Saleema's misery in male-dominated culture is initially a reflection of how control of the economy privileges males to control the female body, constraining her to a bare minimum existence. Ignorant, uneducated, and ensnared into a forced marriage, she is compelled to wage a struggle for existence that assumes the pattern of illicit and extra-marital sexuality.

Importantly sexuality for her is not for any orgasmic fulfilment. Going beyond the essential biological and orgasmic imperatives of sexuality, her body is a source of physical survival and protection in the circumstances. She also acts beyond any recognition of moral imperatives of her action and uses her body to entrap other men from the working class to get financial support. She had to learn the skill and aptitude of survival like living as the "plaything" of the son of the local landowner until she is married off to live in "cramped servant quarter" in the metropolitan city of Lahore. Finding that her husband is a complete debauch, always in need of money "to buy twists of rocket pills" for his "amphetamine addiction" (Ibid., p. 30), she learns to rely upon her youthfulness and transgresses the marital border to sleep regularly with other men like Hassan (a cook) and Rafik (a servant). However, the relations with the sixty-year-old and married Rafik turns out to be the most pathetic expression of how she is consumed for male sexual gratification without any possibility of a protected future, independence and empowerment. She starts sleeping naked each night in his bed and finally getting pregnant with him. Initially, acting beyond shame-shamelessness dichotomy, she works for a level of protection which her husband and previously her parent filed to give her. However, 
'within two years she is finished, began using rocket pills which she once despised ... went on to heroin, leaving her husband behind without a word...' (Ibid., p. 60) and ends up as a beggar in the streets.

In another short story, Provide Provide, Zainab sexuality is strongly tied to her subordinate position in society. She even acts expeditiously to involve local land manager, Jaggalani in fornication and later on marries him under dubious circumstances without obtaining a valid divorce from her first barren husband. Only when she fails to conceive, she discloses her desire to Jaggalani: 'the day we married last year ... you know I thought I didn't have children with Aslam [former husband] because he couldn't. . . . She almost began to cry ... her face became hard. I only married you because of that' (Mueenuddin, 2009: p. 79). She even begs him, 'I never begged, but now I'll beg from you. I'll bow down. I beg you give me one of your son's children to bring up. . . .' (Ibid., p. 79). Zainab's urge for motherhood is apparent here and is connected to a conventional ethical belief that women's natural bodies are replete with reproductive possibilities that give them a privileged, superior ethical position. Like Saleema, her principal motif is not to have an orgasmic sexual experience, or indulge in sexuality for self-empowerment, but to deal with her sense of insecurity and marginalized status. The story titled "In Other Rooms, Other Wonders," depicts how young Husna from a lower class seeks to develop sexual relationships with the very old and debauch KK Harooni only for financial prospects of comfortable living. She understands that in her present condition of poverty, 'she could never hope to marry or attract a young man from one of the rich established families' (Ibid., p. 120). Hardly thinking of losing her virginity to an old married man, she only aims to have a comfortable living: "She could pretend later to be a virgin: or someone would take her even knowing she wasn't. A marriage could always be arranged, it was always a bargain, a deal" (Ibid., p. 128).

\section{The Male Gaze}

The male gaze as Mulvey explains it in her essay "Visual Pleasure and Narrative Cinema" is of critical importance in describing "the manner in which the traditional visual apparatus of mainstream 'Hollywood "narrative" film looks at women as passive objects subordinated' to the male gaze" (Leitch, 2018: p. 2180). Based on Freud's theory of scopophilia and Lacan's mirror stage, Mulvey says that in "patriarchal culture, women are a signifier of the male other, bound by a symbolic order in which man can live out his fantasies and obsessions through linguistic command by imposing them on the silent image of woman still tied to 
her place as bearer, not maker, of meaning" (p. 2088). In her views on the male gaze, Mulvey further articulates:

'The determining male projects its fantasy onto the female figure, which is styled accordingly. In their traditional exhibitionist role women are simultaneously looked at and displayed, with their appearance coded for strong visual and erotic impact so that they can be said to connote to-belooked-at-ness. Woman displayed as sexual object is the leitmotif of erotic spectacle: from pin-ups to striptease, from Ziegfeld to Busby Berkeley, she holds the look, and plays to and signifies male desire' ( $\mathrm{p}$. 2088).

In this context, the female body in Pakistani fiction is a cultural site of "the male gaze" as a number of sexual descriptions of female sexuality in the fiction under discussion parallels the cinematic visual, and therefore signifies an erotic pleasure for male's consummation. The precise description of female adolescent sexual awakening in the Ice-Candy-man and The Pakistani Bride, exact details of the orgasmic intercourse in The Geometry of God, The Bride and "Lilly" as discussed above strongly invite "the male gaze" for specific sexual pleasure. It is also apparent in Carol and Zaitoon's fantasizing of their sexual encounter with adorable, tall and handsome males. It is apparent in Zaitoon's total ignorance of natural sexualized conduct in marriage, allowing her husband Sakhi to perceive her virginity and "the kind of modesty a virgin bride should display" (Sidhwa, 1983, p. 75). Likewise Zaitoon's unawareness of the pubertal changes, and later on her awareness of the wet, burning sensation between the thighs, her act of hugging her chest to ease pubertal aches or the descriptions of her post-puberty indefinable sexual cravings like her longings for the privacy of bath to see and feel her body are replete with the fetishized impressions. Similarly Zaitoon's first sexual experience with Sakhi and the knowledge of her sexualized being like her naked body, "the round out-thrusting breasts" (Ibid., p. 161), "lean string thighs" (Ibid., p. 161) and "the curling jet hair that peeped rebelliously through protective fingers" (Ibid., p. 161) sensationalize adolescent female sexuality for the active "male gaze".

"The male gaze" also enables men to regulate women's sexualities. For instance, men regulate female sexualities in The Pakistani Bride by imposing a ban on women to discuss matters related to sex with anyone. Right from the start, Zaitoon has been made deeply conscious of these rules. Her existence has been defined in terms of living in a "sexual vacuum" (Ibid., p.162). Therefore, when she experiences her sexual awakening, she abstains from speaking about it to anyone. Naturally it keeps her ignorant of sexual cravings and sexual conduct of married 
couples. When she reaches puberty with sensuous uprising and impression, she is unable to express them and even amalgamating sexual feelings and love for family members as is evident in her experience with her stepfather Qasim. Likewise, her first sexual experience after marriage also becomes a terrible nightmarish experience, twisting and convulsing her body in terrible pain and trauma. Briefly, the subjective expression as well as Zaitoon's responses to sexual awakening in The Pakistani Bride, though challenge the essentialist male sexual discourse, but clashes with the conventional gendered norms which question female sexual awareness and her interests in the body as strictly restrictive. Any act that involves an interest in the body is considered as prohibitive incursions and categorically linked with shamelessness in women.

\section{Commodity Fetishism}

The exchangeability of the female body, beauty and ornamentation with male sexual desire is a modernist approach to study women's impression and status in global advertising and media representation. My contention here is related to how ornamenting takes place in a literary text and how it undermines women's status as a commodity for male sexual desire. Predominantly, women's appearance in a literary text is not contingent upon an artificial decoration. Nevertheless, it can be stated that greater visibility of the sexualized aspects of the female body and elaborate descriptions of her sexual acts can safely be precluded with creating visual images of her body for male sexual desires; creating a fetishized impression for male consummation, which strengthen masculinity at the cost of women appearance. The same condition applies to the sexualized representation of the female body in Pakistan fiction, as analyzed above. The paradoxes of female sexuality can also be substantiated concerning fetishism, especially commodity fetishism, as Marx theorized it. In Fetishism and Curiosity, Mulvey constructs a comparative analysis of Marx and Freud's position on commodity fetishism and fetishism respectively. While, the Marxist position is an essential component of capitalist economies, Freudian position tends to relate it to psychoanalysis. Marxist commodity fetishism is "derived from the problem of inscription," which is, "how does the sign value come to be marked onto a commodity?" (Mulvey, 1996: p. 2). It is one of the cornerstones of the capitalist economies which move around the problem of "establishing exchange value of the actual objects." Freudian Fetishism on the other hand is about "phantasmatic inscription," i.e., ascribing excessive value to the objects considered otherwise to be valueless as the substitute for something else..." (Ibid., pp. 2-3). Both, however, lead us to understand the "social and sexual construction of things at intractable points that trouble the social and 
sexual psyche" (Ibid., p. 3). If applied to the above descriptions of female body, both terms embody a symbolic significance to understand how enunciation of female sex, her body, her sexual pleasures, description of pubertal changes and sexual awakening, first marital sexual description, desire for proactive vaginal sex serve to tract the male "producers" (Commodity Fetishism) and male sexual psyche (Freud). Marxist explication of commodity fetishism serves further to create:

'disavowal of the source of its value in labor power. This process entails a fantasy of disavowal. A commodity's market success depends on the erasure of the marks of production, any trace of indexicality, the grime of the factory, the mass moulding of the machine, and most of all, the exploitation of the worker. Instead, the commodity presents the market with a seductive sheen, as it competes to be desired' (Ibid., p. 4).

Thus, as Mulvey explains,

'Commodity fetishism triumphs as spectacle. As a spectacle, the object becomes image and belief, and is secured by an erotic, rather than a religious, aura ... It is well known that the fetish very often attracts the gaze. In popular imagination, it glitters. It has to hold the fetishist's eyes fixed on the seduction of belief to guard against the encroachment of knowledge. This investment in surface appearance enhances the phantasmatic space of the fetish and sets up a structure in which object fixation can easily translate into image' (Ibid., p. 4).

\section{Conclusion}

The representation of female sexuality in Pakistani fiction offers a few important point of view. It represents that female sexuality is more about the interaction between the individual and society, in the construction of gender position. Through the bold treatment of once considered tabooed subject, the authors have critiqued the prevalent social norms and double standards that control and discipline the bodily behaviors of women. By describing women's sexual pleasure or desires, they expose the framework of power and transgressions on the part of women. But this transgression remains only a temporary phase in women's life as in a majority of cases as analyzed, and it is against both the unspoken and explicit rules that maintain a particular social order. Hence, they are bound to be strongly overwhelmed by the structural patriarchy. Furthermore, the transgressions are bound to collide with the dominant hierarchies and are therefore inevitable to be taken as subversive, causing even further regulation and control. It also needs to be 
ascertained that female sexuality is described in a way that is related to the ethnocentric notion of the western feminism which as Mohanty says, splits the Western and non-western into two disparate groups with the confirmed superiority of the Western over the non-western based on their education, independence and ability to possess control of their sexuality. (Mohanty, 2003). This factor concurs with women in Mueenuddin's short stories and The Pakistani Bride. Then the bold treatment of female sexuality does not emancipate women from exclusion and subordination or present a desirable permanent space for encountering patriarchy and domination. It is a cultural fact that a patriarchal power structure persists and in fact, keeps on growing in intensity in the form of forced marriages, marriages for dowry, violence against women at home and growing incidents of honor killing/acid throwing on women leading to even stricter regulations and constraints. Therefore, women's attempt to construct independent subjectivities the women is difficult if not impossible, to foresee in modern Pakistani fiction. From the author's diaspora perspective, the initial reaction to the explicit female sexuality could be one of a symbolic expression of "new' form of aesthetic freedom" (Nasta, 2001, p. 4), accrued to them by their stay in a liberal context, where independent of "a number of significant limitations" (Ibid., p. 4) they can map out boldly the plain female sexualities. But, the ultimate impression of female sexuality is not of empowerment for them, but effective reinsertion of misogyny and commodification/ objectification of women as inferior, sexually sentient and erotic being. Lastly, religious injunctions have not impacted the expression of female sexualities in all the text analyzed above. Except in the case of Aneeka, all other female characters in the analyzed fiction disconcert Islamic permissibility/impermissibility binaries on pre-marital or extramarital sex.

\section{References}

Ali, A.H., (2006). The caged virgin: an emancipation proclamation for women and Islam. New York: Simon and Schuster.

Ashcroft, B., Griffiths, G., and Tiffin, H. (eds)., (1995). Introduction. Post-colonial Studies Reader. London: Routledge.

Brook, B. (2014). Feminist perspectives on the body. London: Routledge.

Butler, J. (1999). Gender Trouble: Feminism and the Subversion of Identity. Routledge.

Chaudary, F. (2013). Hiding and Seeking Identity: The Female Figure in the Novels of Pakistani Female Writers in English: A Feminist Approach. Doctoral thesis, University of Huddersfield.

Chodorow, N.J., (2014). Femininities, masculinities, sexualities: Freud and beyond. University Press of Kentucky. 
Crockett, L.J., Raffaelli, M., and Moilanen, K. L. (2003). Adolescent sexuality: Behavior and meaning. Faculty Publications, Department of Psychology, p. 245.

Davies, B. (1991). 'The concept of agency: A feminist poststructuralist analysis.' Social Analysis: The International Journal of Social and Cultural Practice, (30), pp. 42-53.

Espin, O. (2013). Women crossing boundaries: A psychology of immigration and transformations of sexuality. Routledge.

Fortenberry, J.D. (2013). 'Puberty and adolescent sexuality.' Hormones and behavior, 64(2), pp. 280-287.

Henningsen, D.D., Henningsen, M.L.M., and Valde, K.S. (2006). Gender differences in perceptions of women's sexual interest during cross-sex interactions: An application and extension of cognitive valence theory. Sex Roles, 54(11-12), pp. 821-829.

Hubbard, S.D. (1976). 'Social Pressures on Feminine Sexuality.' Frontiers: A Journal of Women Studies, pp. 31-33.

Idriss, M.M., and Abbas, T. eds., (2010). Honour, violence, women and Islam. Routledge.

Kanneh, K. (1995). "Feminism and the Colonial Body" In Bill Ashcroft, Gareth Griffiths and Helen Tiffin (eds.). The Post-colonial Studies Reader. London: Routledge.

Katrak, K. (2006). The Politics of the Female Body: Postcolonial Women Writers. Rutgers University Press.

Khan, Uzma Aslam. (2007). The Geometry of God. Lahore: ilqa.

Kiefer, A.K., and Sanchez, D.T. (2007). 'Scripting sexual passivity: A gender role perspective.' Personal Relationships, 14(2), pp. 269-290.

Kureshi, Hanif. (1999). Midnight all Day. Faber and Fabre.

Leitch, V.B., et al. (eds.), (2018). The Norton Anthology of Theory and Criticism. WW Norton \& Company.

McLaren, M.A. (1997) 'Foucault and the subject of feminism.' Social Theory and Practice, 23(1), pp.109-128.

McNay, L. (2013). Gender and agency: Reconfiguring the subject in feminist and social theory. John Wiley \& Sons.

Mernissi, F. (1982). January. Virginity and patriarchy. In Women's Studies International Forum (Vol. 5, No. 2, pp. 183-191). Pergamon.

Mohanty, C. (1988). Under Western eyes: Feminist scholarship and colonial discourses. Feminist Review, 30(1), pp.61-88.

Mueenuddin, D. (2009). In Other Rooms, Other Wonders. London: Bloomsbury.

Mulvey, L. (2010) 'Visual Pleasure and Narrative Cinema' in Leitch, V. B. et al. (eds.). The Norton Anthology of Theory and Criticism. Second Edition. New York: Norton.

--. (1996). Fetishism and curiosity. Indiana University Press.

Nash, M. (2012). Weighty matters: Negotiating 'fatness' and 'in-betweenness' in early pregnancy. Feminism \& Psychology, 22(3), pp.307-323.

Nasta, S. (2001). Home truths: fictions of the South Asian diaspora in Britain. Macmillan International Higher Education.

Naqvi, HM. (2010). Home Boy. HarperCollins

Price, J \& Shildrick, M. (1999). 'Opening on the Body: A Critical Introduction' in Price, J and Shildrick, M. (eds.). Feminist theory and the body: A Reader. New York: Routledge. 
Rich, A. (1980). 'Compulsory heterosexuality and lesbian existence' in Leitch, V. B. et al. (eds.). The Norton Anthology of Theory and Criticism. Second edition. New York: Norton. 2018.

Seidler, V.J. (2013). Unreasonable men: Masculinity and social theory. Routledge.

Shamsie, K. (2017). Home Fire. London: Bloomsbury

Shamsie, M. (2017). Hybrid Tapestries: The Development of Pakistani Literature in English. Lahore: Oxford.

Shannahan, D.S. (2009). Sexual ethics, marriage, and sexual autonomy: the landscapes for Muslimat and lesbian, gay, bisexual, and transgendered Muslims. Contemporary Islam, 3(1), pp.59-78.

Sidhwa, B. (1983). The Pakistani Bride. New Delhi: Penguin.

--. . (2012). Ice- Candy-man. Lahore: Ilqa Publications.

Yip, A.K.T. (2009). Islam and sexuality: orthodoxy and contestations. Contemporary Islam, 3(1), pp.1-5.

Yahyaoui, A., El Methni, M., Gaultier, S., and Lakhdar-Yahyaoui, D.B.H. (2013). Acculturative processes and adolescent sexuality: A comparative study of 115 immigrant adolescents from cultures influenced by Islam and 115 French adolescents from cultures influenced by Christianity. International Journal of Intercultural Relations, 37(1), pp.28-47. 